\title{
Społeczna inspekcja pracy niezbędny instrument społecznego (związkowego) nadzoru nad przestrzeganiem prawa pracy
}

\section{Social labour inspectorate - a necessary instrument of civil (trade union's) supervision over compliance with labour law}

\author{
dr hab. prof. UMCS Teresa Liszcz \\ Uniwersytet Marii Curie-Skłodowskiej w Lublinie
}

\begin{abstract}
Streszczenie Autorka uważa, wbrew poglądom niektórych innych przedstawicieli doktryny, że należy utrzymać społeczną inspekcję pracy, jako najważniejszy instrument społecznego nadzoru nad przestrzeganiem prawa pracy przez pracodawców i warunkami pracy, będący w istocie agendą związków zawodowych. Społeczni inspektorzy pracy, wybrani przez pracowników z ich grona, są świetnie obeznani z warunkami pracy w zakładzie pracy i mogą skutecznie wspierać, a nawet w pewnym zakresie zastępować, działanie Państwowej Inspekcji Pracy. Konieczne jest jednak przyjęcie nowej ustawy o społecznej inspekcji pracy, ponieważ obowiązująca ustawa z 1950 r. zawiera wiele błędnych rozwiązań. W szczególności pracodawca nie powinien decydować o przyznaniu społecznemu inspektorowi wynagrodzenia z tytułu pełnienia tej funkcji ani go finansować, gdyż to uzależnia inspektora od pracodawcy.
\end{abstract}

Słowa kluczowe: społeczna inspekcja pracy, społeczny inspektor pracy, przestrzeganie prawa pracy, bezpieczeństwo i higiena pracy, pracodawca, związek zawodowy.

Summary The author is of the opinion, contrary to views presented by some other scholars of labour law, that the social labour inspectorate must remain the most important instrument of civil supervision over employers' compliance with labour law and work conditions, actually constituting an agency of trade unions. Social labour inspectors, chosen by employees from among them, are well acquainted with working conditions at their workplace and can effectively support, and even to some extent replace, the activities of the State Labour Inspectorate. However, it is necessary to adopt a new Act on social labour inspection, as the currently applicable Act of 1950 contains many erroneous solutions. In particular, it should not be the employer who decide on granting the social inspector remuneration for performing this function or subsidising him or her, as this makes the inspector dependent on the employer.

Keywords: social labour inspectorate, social labour inspector, labour law compliance, occupational health and safety, employer, trade union.

JEL: K31

Str. 2-11

\section{Bibliografia}

Bojanowski, W. (2001). Społeczny nadzór nad warunkami pracy. Materiat szkoleniowy. Warszawa: Wyd. Głównego Inspektora- tu Pracy. Gaza, Ł. (2006). Parasol ochronny przed zwolnieniami. Gazeta Prawna, portal „Waluty.com” z 2 kwietnia 2006 r.

Kozieł, W. (1988). Ustawa o spolecznej inspekcji pracy. Komentarz. Warszawa.

Książek, D. (2016). Komentarz do ustawy o społecznej inspekcji pracy (komentarz do art. 3). W: W. Kozieł (red.), Zbiorowe prawo pracy. Komentarz. Warszawa.

Pettke, P. (2009). Społeczna inspekcja pracy — instytucja minionego czasu. Praca i Zabezpieczenie Spoteczne, (8).

Rączka, K. (2008). Co dalej ze społeczną inspekcją pracy — felieton. Praca i Zabezpieczenie Społeczne, (9).

Rutkowski, T. (2005). Spoleczny nadzór nad warunkami pracy. Informator. Warszawa.

Sanetra, W. (2001). Komentarz do ustawy o społecznej inspekcji pracy (komentarz do art. 3). W: W. Sanetra (red.), Prawo socjalne. Warszawa. 